\title{
Innovation activity impact on adding value to the enterprise: empirical analysis
}

\author{
Idelia Badykova ${ }^{1, *}$, and Anna Romanova ${ }^{2}$ \\ ${ }^{1}$ Kazan National Research Technological University, Kazan, Russia \\ ${ }^{2}$ Kazan State University of Architecture and Engineering, Kazan, Russia
}

\begin{abstract}
In the context of economy digitalization corporate innovative activity is one of the main competitive advantages, which should have impact on adding value to the enterprise. The aim of this study is to explore if there is relation between innovation activity level of the Russian companies and their value. Analysis of balanced panel data based on the application of random effects and fixed effects models is used to test research hypotheses. The sample contains 19 Russian nonfinancial public companies (2012-2019). The results of the empirical study demonstrate the positive relation between corporate innovation activity level and company value. The influence of expenditures on staff development (one of the corporate social responsibility (CSR) directions) on the latter is addressed as well, however, no statistically significant result is received in the short run, probably confirmation of a positive relationship can be obtained in the long term. Moreover, impact of general CSR indicator on corporate value can be tested to make further conclusions on the validity of the idea of joint influence of innovation activity and CSR on the value of companies.
\end{abstract}

\section{Introduction}

In the context of economy digitalization innovative development of the economy has been gaining growing popularity both in academic and managerial circles. Innovation activity is an important tool for achieving corporate economic efficiency, including enterprise value growth. It can be presumed that improvements of that kind are achieved partly owing to a positive reaction from various groups of stakeholders. However, low level of information transparency in matters of innovation in Russia is a significant problem, which leads to the fact that external stakeholders may underestimate the company's potential. As a result, business has to bear opportunity costs.

The development and implementation of innovations is an essential condition for the development of enterprises, industries, and states. The most significant factors of innovative activity growth are investigated by Schumpeter [1], Maclaurin [2], Penrose [3], Porter [4], Wernerfelt [5], Arrow [6], Tirole [7], and others.

The relationship between the level of innovative activity and the value of the company is of high interest as well. Innovation activity is one of the most promising directions in adding value to the companies, since it opens up new opportunities for production, sales,

\footnotetext{
*Corresponding author: idelya.nizamova@gmail.com
} 
organization of production and sales, management, etc. Nonetheless, the high risk level is not always acceptable for some market participants.

The study aims to discover relation between innovation activity and company value within the Russian market.

\section{Literature Review}

Schumpeter [1] was the first scientist to state that technological innovations are factors that influence corporate performance. Sufficient number of theoretical and empirical studies have been carried out on this issue. For example, Faems, Lui, and Debaker [8] consider technological innovation as a corporate strategy for the companies' survival and competitiveness growth.

Kim and Choi [9] inspect the positive impact of innovation on the economic efficiency of companies. Zhang et al. [10] claim product innovations to be an essential direction of companies' activities to reach the growth. M. Pinto et al. [11] consider the importance of introducing technological innovations to the field of healthcare, business and the environment in order to create new jobs.

Innovations can affect corporate financial performance with different level of significance depending on company characteristics and timing [12]. Nonetheless, it is hard to argue with Koc and Ceylan [13], stating that innovation is the most common strategy for increasing corporate growth.

Innovations making a vital contribution to sustainable development seems to be obvious. Thus, sufficient impact should be seen in terms of economic and social efficiency, including corporate value.

Studies taken by Griliches [14], Hall et. al [15], Sandner and Block [16], Rahko [17], Bouaziz [18], Bierly and Chakrabarti [19], Liao and Rice [20], Zhong [21] provide prove to the theory of innovation activity and corporate value being positively related.

We find it reasonable to conduct an empirical study of the relationship between innovation activity and company value within the Russian market. This analysis can be helpful for companies when developing long-term strategy.

\section{Methods}

The research is based on statistical analysis of the sample containing data on 19 Russian nonfinancial public companies in 2012-2019. Within the scope of current research innovation activity is considered as the ratio of $R \& D$ expenditures to revenue. The sample is represented by large companies, which tend to provide information of $R \& D$ expenditures as one of the main parameters of their innovative activities, that gives us the reason to believe this variable to be appropriate.

Figure 1 presents a histogram showing the average values of the ratio of $R \& D$ expenditures to revenue within the considered sample in 2012-2019. The dashed line demonstrates the trend line.

It can be seen that in 2015 and 2016 there was a sufficient leap in the growth of the ratio of R\&D expenditures to companies' revenue. Most likely, after the multiple crises (the world economic crisis, the currency crisis in Russia, etc.), it became harder for the companies to underestimate the importance of innovative development. However, in 2017 was a fall, which can be explained by the fact that according to the estimates of the Government of the Russian Federation, the Russian economy came out of the crisis. As a result, the growth rate of R\&D expenses was lower than the growth rate of revenue, which led to a decrease in the ratio of R\&D expenses to revenue. Subsequently, the fluctuations were insignificant. Nevertheless, 
the trend line shows that the indicator tends to grow (compared to 2012, in 2019 the indicator was 1.9 times higher).

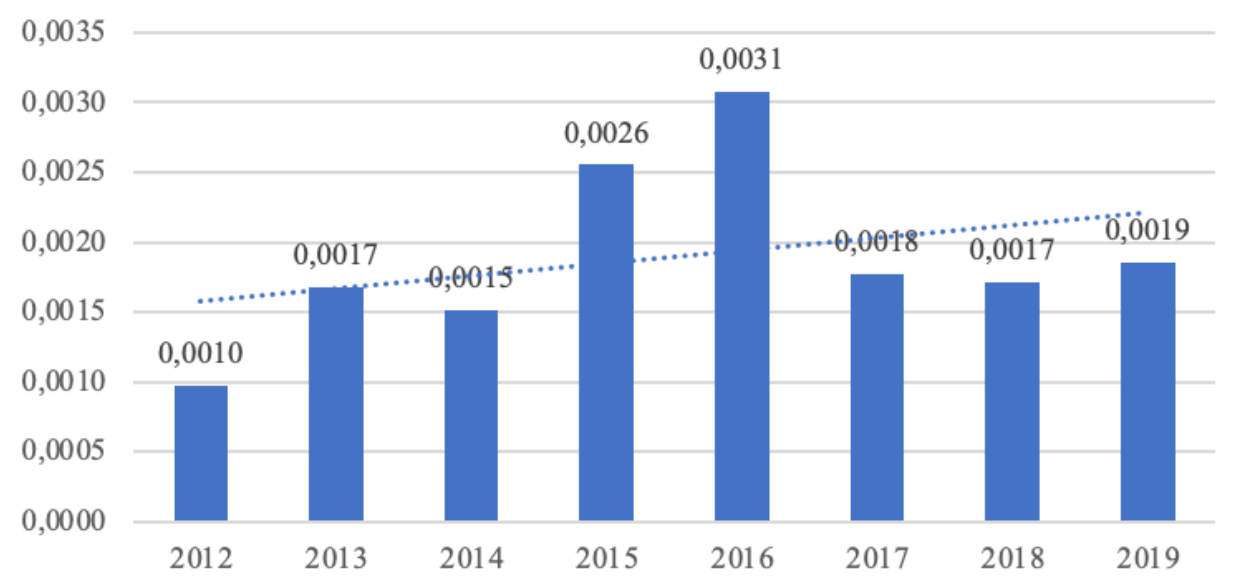

Fig. 1. Average values of the ratio of $R \& D$ expenditures to revenue of enterprises within the considered sample in 2012-2019

It can be concluded, that the values of the indicator fluctuate quite significantly during the reviewed period, which may indicate a weak policy of innovative development and a lack of understanding by of the key importance of investments in innovative activities by managers.

The price / book value (MBR) multiplier will be considered as a cost indicator. In addition, in order to avoid the endogeneity problem, control variables are added to the model: the level of expenses for staff development, EBITDA margin, the size and age of the company, and financial leverage. Also, dummy variables are used to indicate sectoral affiliation and timing to consider macroeconomic conditions.

Thus, the following hypotheses were tested:

$H_{1}$ : The level of innovation activity is positively correlated to the corporate value.

Despite the fact that innovative activity leads to the risk growth, it is an essential part to contemporary companies' development. It can be assumed that stakeholders, including prospective investors, will be interested in indicators related to the innovative activity of an organization when making decisions about cooperation with an enterprise.

$\mathrm{H}_{2}$ : The level of expenses for training and professional development of personnel negatively affects the value of the company in the current period.

The effect is considered in the short run. The experience of Russian companies prompts this kind of expenses to be considered as current costs, and not medium and long-term investments. Most likely, in the medium and long term period the result should be the opposite. Within the framework of this study, the identification of such patterns of the influence of investments in human capital is not the main goal. Therefore, only the relationship in the current period will be considered.

$H_{3}$ : The higher profitability leads to the higher company value.

The high level of economic efficiency indicates that the company has competitive advantages, which will be essential for investors when choosing an investment object. Accordingly, such attention from shareholders will lead to an increase in the company's value.

$H_{4}$ : Enterprise value is positively related to the leverage level.

Companies, that are able to attract borrowed funds, tend to be seen as financially stable. Thus, the market value should be positively influenced by the fact of high level of financial 
leverage. Also, a high level of debt financing in the capital structure leads to a decrease in its WACC, as a result, the corporate value grows.

$H_{5}$ : The age of the company has a negative impact on financial performance.

The negative impact may be explained by the fact that the great company age may indicate that the enterprise is losing the ability to generate economic rents. In addition, such companies often seek to carry out traditional activities to avoid high-risk innovation projects, which can probably also be considered as the reason for such a connection.

$H_{6}$ : Firm size has a positive effect on the value creation potential of the enterprise.

Large institutional stocks, usually being more liquid, result in investors agreeing to buy share in a higher price. Also, significant resources contribute to the fact that companies are able to generate high returns. Practice shows that large companies tend to be more open to implementing innovative projects, which, in our opinion, is also an essential aspect.

\section{Results}

Table 1 demonstrates descriptive statistics of variables for the period 2012-2019.

Table 1. Descriptive data statistics for 2012-2019.

\begin{tabular}{|c|c|c|c|c|c|}
\hline Variable & Description & Mean & SD & Min & Max \\
\hline $\begin{array}{l}\text { MBR (price / } \\
\text { book value) }\end{array}$ & $\begin{array}{c}\text { Capitalization / } \\
\text { Accounting Value }\end{array}$ & 1.2428 & 0.8703 & 0.1385 & 4.3027 \\
\hline $\begin{array}{l}\text { Level of } \\
\text { innovation } \\
\text { activity }\end{array}$ & $\begin{array}{l}\text { R\&D expenses / } \\
\text { Revenue }\end{array}$ & 0.0019 & 0.0051 & 0 & 0.0433 \\
\hline $\begin{array}{c}\text { Level of } \\
\text { expenditures on } \\
\text { staff development }\end{array}$ & $\begin{array}{l}\text { Expenses for training } \\
\text { and advanced training } \\
\text { of personnel / Payroll }\end{array}$ & 0.0046 & 0.0028 & 0.0003 & 0.0121 \\
\hline EBITDAmargin & EBITDA / Revenue & 0.2370 & 0.1125 & 0.0478 & 0.5564 \\
\hline Leverage & $\begin{array}{c}\text { Amount of short-term } \\
\text { and long-term loans / } \\
\text { Amount of equity and } \\
\text { debt funds }\end{array}$ & 0.4716 & 0.1737 & 0.1017 & 0.8883 \\
\hline Age & $\begin{array}{l}\text { Years from the date of } \\
\text { company registration }\end{array}$ & 19.4013 & 5.6066 & 6 & 28 \\
\hline Size & $\begin{array}{c}\text { Natural logarithm of } \\
\text { revenue }\end{array}$ & 12.4696 & 1.3650 & 9.4669 & 15.8994 \\
\hline $\begin{array}{l}\text { Affiliation to } \\
\text { Mining Sector }\end{array}$ & \multirow{3}{*}{$\begin{array}{l}\text { Dummy Variable: } \\
=1 \text { if relevant; } \\
=0 \text { otherwise }\end{array}$} & 0.5263 & 0.5010 & 0 & 1 \\
\hline $\begin{array}{l}\text { Affiliation to } \\
\text { Manufacturing } \\
\text { Sector }\end{array}$ & & 0.3684 & 0.4840 & 0 & 1 \\
\hline $\begin{array}{l}\text { Affiliation to } \\
\text { Transport and } \\
\text { Telecommunicati } \\
\text { ons Sector }\end{array}$ & & 0.1053 & 0.3079 & 0 & 1 \\
\hline $\begin{array}{l}\text { Time dummy } \\
\text { (2012) }\end{array}$ & \multirow{2}{*}{$\begin{array}{l}\text { Dummy variable: } \\
=1 \text { if the data refers to } \\
\text { the specified year; } \\
=0 \text { otherwise }\end{array}$} & 0.125 & 0.3318 & 0 & 1 \\
\hline $\begin{array}{c}\text { Time dummy } \\
\text { (2013) }\end{array}$ & & 0.125 & 0.3318 & 0 & 1 \\
\hline
\end{tabular}




\begin{tabular}{|c|c|c|c|c|}
\hline $\begin{array}{l}\text { Continuation of } \\
\text { table } 1\end{array}$ & & & & \\
\hline $\begin{array}{l}\text { Time dummy } \\
\text { (2014) }\end{array}$ & 0.125 & 0.3318 & 0 & 1 \\
\hline $\begin{array}{l}\text { Time dummy } \\
\text { (2015) }\end{array}$ & 0.125 & 0.3318 & 0 & 1 \\
\hline $\begin{array}{l}\text { Time dummy } \\
\text { (2016) }\end{array}$ & 0.125 & 0.3318 & 0 & 1 \\
\hline $\begin{array}{l}\text { Time dummy } \\
\text { (2017) }\end{array}$ & 0.125 & 0.3318 & 0 & 1 \\
\hline $\begin{array}{c}\text { Time dummy } \\
(2018)\end{array}$ & 0.125 & 0.3318 & 0 & 1 \\
\hline $\begin{array}{c}\text { Time dummy } \\
(2019)\end{array}$ & 0.125 & 0.3318 & 0 & 1 \\
\hline
\end{tabular}

According to the table 1, the average level of innovation activity in the sample is 0.0019 $(0.19 \%)$. The spread is quite wide (from 0 to $4.33 \%$ ).

In order to eliminate the problem of multicollinearity between the independent variables, a correlation analysis was carried out (Table 2). The maximum value of the correlation can be observed between companies' investments in staff development and the size of the company (0.4493), however, for values below 0.5 , the sample does not need to be adjusted. The results are satisfactory and suggest that the problem has not been detected and does not need to be addressed.

Table 2. Results of correlation analysis (Pearson matrix).

\begin{tabular}{|c|c|c|c|c|c|c|}
\hline Variable & $\begin{array}{c}\text { Level of } \\
\text { innovation } \\
\text { activity }\end{array}$ & $\begin{array}{c}\text { Level of } \\
\text { expenditures } \\
\text { for staff } \\
\text { development }\end{array}$ & $\begin{array}{c}\text { EBITDAmarg } \\
\text { in }\end{array}$ & Size & Age & Leverage \\
\hline $\begin{array}{c}\text { Level of innovation } \\
\text { activity }\end{array}$ & 1.0000 & & & & & \\
\hline $\begin{array}{c}\text { Level of } \\
\text { expenditures for } \\
\text { staff development }\end{array}$ & 0.1140 & 1.0000 & & & & \\
\hline EBITDAmargin & -0.0656 & 0.0686 & 1.0000 & & & \\
\hline Size & 0.2054 & 0.4493 & -0.0754 & 1.0000 & & \\
\hline Age & 0.0428 & -0.0704 & 0.1185 & 0.2923 & 1.0000 & \\
\hline Leverage & 0.0571 & -0.2763 & -0.2184 & -0.2538 & 0.1539 & 1.0000 \\
\hline
\end{tabular}

The analysis of balanced panel data was used to conduct this study. This method relies on random and individual fixed effects models. It takes into account unobservable effects, which are determined by the individual characteristics of the companies. For the study, the STATA 13.0 software package is used. The results are presented in table 3. 
Table 3. Results of assessing the impact of determinants on corporate value.

\begin{tabular}{|c|c|c|}
\hline \multirow[t]{2}{*}{ Variables } & \multicolumn{2}{|c|}{ Models } \\
\hline & RE-model & FE- model \\
\hline Level of innovation activity & $\begin{array}{c}28.1300 \\
(3.85) * * *\end{array}$ & $\begin{array}{c}40.7988 \\
(6.04)^{* * *} \\
\end{array}$ \\
\hline Level of expenditures on staff development & $\begin{array}{c}-22.9060 \\
(-0.53)\end{array}$ & $\begin{array}{r}-3.4322 \\
(-0.09) \\
\end{array}$ \\
\hline EBITDAmargin & $\begin{array}{c}2.9736 \\
(3.23)^{* * *}\end{array}$ & $\begin{array}{c}3.4360 \\
(3.44)^{* * *}\end{array}$ \\
\hline Size & $\begin{array}{c}0.0560 \\
(0.45)\end{array}$ & $\begin{array}{c}0.5936 \\
(1.41)\end{array}$ \\
\hline Leverage & $\begin{array}{c}0.1762 \\
(0.21) \\
\end{array}$ & $\begin{array}{c}-0.0484 \\
(-0.06) \\
\end{array}$ \\
\hline Age & $\begin{array}{l}0.0543 \\
(1.66)^{*}\end{array}$ & $\begin{array}{c}-0.8126 \\
(-3.85)^{* * *}\end{array}$ \\
\hline Affiliation to Mining Sector & $\begin{array}{l}0.0806 \\
(0.16)\end{array}$ & 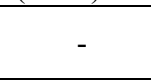 \\
\hline Affiliation to Manufacturing Sector & $\begin{array}{l}0.1258 \\
(0.26)\end{array}$ & - \\
\hline $\begin{array}{l}\text { Affiliation to Transport and } \\
\text { Telecommunications Sector }\end{array}$ & - & - \\
\hline Time dummy (2013) & $\begin{array}{c}-0.2103 \\
(-2.21)^{* *}\end{array}$ & $\begin{array}{c}0.6395 \\
(3.14)^{* * *}\end{array}$ \\
\hline Time dummy (2014) & $\begin{array}{c}-0.3960 \\
(-2.17)^{* *}\end{array}$ & $\begin{array}{c}1.2855 \\
(2.96) * * *\end{array}$ \\
\hline Time dummy (2015) & $\begin{array}{c}-0.4414 \\
(-2.23)^{* *}\end{array}$ & $\begin{array}{c}2.0436 \\
(3.07)^{* * *}\end{array}$ \\
\hline Time dummy (2016) & $\begin{array}{c}-0.1910 \\
(-0.78)\end{array}$ & $\begin{array}{c}3.0826 \\
(3.09)^{* * *}\end{array}$ \\
\hline Time dummy (2017) & $\begin{array}{l}-0.1909 \\
(-0.71)\end{array}$ & $\begin{array}{c}3.9120 \\
(3.21)^{* * *}\end{array}$ \\
\hline Time dummy (2018) & $\begin{array}{c}-0.2144 \\
(-0.72)\end{array}$ & $\begin{array}{c}4.6685 \\
(3.14)^{* * *} \\
\end{array}$ \\
\hline Time dummy (2019) & $\begin{array}{c}-0.1804 \\
(-0.56)\end{array}$ & $\begin{array}{c}5.6291 \\
(3.28)^{* * *}\end{array}$ \\
\hline Const. & $\begin{array}{c}-1.1056 \\
(-0.72)\end{array}$ & $\begin{array}{c}6.0953 \\
(0.79)\end{array}$ \\
\hline R2 (within) & 0.2847 & 0.3333 \\
\hline Wald / F & $227.85 * * *$ & $4.61 * * *$ \\
\hline Breusch-Pagan / Hausman test & $46.53 * * *$ & $19.36 *$ \\
\hline
\end{tabular}

Note: Estimates of the determinants impact on company's value are presented by the use of models with random (RE) and fixed (FE) effects. The values for t-statistics corrected for heteroscedasticity are indicated in brackets. The models include industry dummy variables (excluding fixed effects models) and time dummy variables (2013-2019). Wald statistic and F statistic are used to test the joint significance of independent variables in random and fixed effects models, respectively. The Breusch-Pagan test is presented to compare models with random effects and pooled regressions, the Hausman test is given to compare fixed effects models to random effects models.

$* * *$ significance level of $1 \%, * *$ significance level of $5 \%, *$ significance level of $10 \%$. 
The models are statistically significant according to the F-test (fixed effects model) and Wald's test (random effects model). despite the fact that the coefficients of determination are quite low.

Hausman's test suggests that at the $10 \%$ significance level the fixed effects model is better at explaining the relationship between the resulting and explanatory variables than the model with random effects. Accordingly, the results of the fixed effects model will be considered. It should be noted that this model does not determine the coefficients for dummy variables that reflect industry affiliation with permanent value.

The obtained results support the idea of innovation activity level being positively correlated to the value of the company, since the coefficient of the variable turned out to be positive and statistically significant. At the same time, it represents a high value (40.7988), which indicates a high level of influence. Therefore, it can be stated that the companies' innovative development is attractive for various groups of stakeholders, including investors.

The hypotheses related to control variables about the positive impact of EBITDA margin and negative of the age on the company's value is proved for the Russian market as well. Accordingly, we can conclude that the high level of the company's income leads to further growth of the company in terms of its value.

The hypotheses related to the influence of the level of expenses on staff development, leverage and company size and their effect on innovation activity level were not confirmed.

As the analysis has shown, the macroeconomic environment has a significant impact on the value of companies, as evidenced by statically significant coefficients of time dummy variables, which show growth throughout the entire period under consideration.

Thus, the conducted empirical study allows us to conclude that the level of innovation activity has a positive effect on the value growth of Russian companies. Accordingly, it seems reasonable for companies to develop a quality innovative strategy of the company.

\section{Discussion}

The research conducted by the authors for the Russian market indicates a positive relationship between the level of innovation activity and the value of enterprises.

As any empirical study, this research is subject to a number of limitations. The most important one is the small sample size. Nevertheless, the obtained models are statistically significant and allow us to conclude that there is a positive relationship between the level of innovative activity and the corporate value in Russian market.

Within the framework of this study, the model includes an indicator of the level of expenditures on staff development, which, in our opinion, represents the direction of CSR. In our opinion, further inclusion of the general indicator of CSR in the model seems promising.

Innovation activity together with CSR policy is an important tool for achieving corporate economic efficiency, including enterprise value growth. It can be presumed that improvements of that kind are achieved partly owing to a positive reaction from various groups of stakeholders to both of the mentioned areas of companies' activities. Thus, proactivity in terms of innovation and CSR can be accepted as a signal of company being successful, reliable, etc. Despite the fact that innovations are often associated with a high level of risk, a quality CSR programme undertaken simultaneously makes it possible to mitigate those risks. 


\section{References}

1. J. A. Schumpeter, Business cycles: A theoretical, historical, and statistical analysis of the capitalist process (New York: McGraw-Hill, 1939)

2. W. R. Maclaurin, Am. Econ. Rev. 40, 90 (1950)

3. E. T. Penrose, The theory of the growth of the firm (Oxford: Basil Blackwell, 1959)

4. M. E. Porter, Competitive Strategy (New York: Free Press, 1980)

5. B. Wernerfelt, Strat. Man. J. 5, 171 (1984)

6. K. Arrow, The rate and direction of inventive activity (Princeton: Princeton University Press, 1962)

7. J. Tirole, The theory of industrial organization (Cambridge: The MIT Press, 1997).

8. D. Faems, B. Van Looy, K. Debackere, J. of Prod. Innov. Man. 22, 238 (2005)

9. D. G. Kim, S.O. Choi, Sustainability 10, 3972 (2018)

10. Y. Zhang, U. Khan, S. Lee, M. Salik, Sustainability 11, 495 (2019)

11. M. M. A. Pinto, J.L. Kovaleski, R.T. Yoshino, R.N. Pagani, Sustainability 11, 3485 (2019)

12. R. C. M. Yam, W. Lo, E.P.Y. Tang \& K.W. Lau, World Acad. Sc. Engin. Techn., 42, 1009 (2010)

13. T. Koc, C. Ceylan, Technovation, 27, 105 (2007)

14. Z. Griliches, $R \& D$, patents, and productivity (Chicago: National Bureau of Economic Research, University of Chicago Press, 1984)

15. B. H. Hall, A. Jaffe, M. Trajtenberg, RAND J. of Econ., 36, 16 (2005)

16. P. G. Sandner, J. Block. Res. Pol. 40, 969 (2011)

17. J. Rahko, J. Econ. of Innov. and New Techn. 23, 353 (2014)

18. Z. Bouaziz, J. of B. Th. and Pract. 4, 51 (2016)

19. P. Bierly, A. Chakrabarti, Strat. Man. J. 17(S2), 123 (1996)

20. T.-S. Liao, J. Rice, Res. Pol. 39(1), 117 (2010)

21. R. Zhong. J. of Ac. and Econ. 1(66), 67 (2018) 